\title{
A development in balanced scorecard by designing a fuzzy and nonlinear Algorithm (case study: Islamic Azad university of Semnan)
}

\author{
Afsaneh Mozaffari ${ }^{a}$, Hamidreza Karkehabadi ${ }^{b^{*}}$, Mahdi Kheyrkhahan ${ }^{c}$ and Mosayeb Karamib
}

\author{
Article history: \\ Received December 18, 2011 \\ Received in Revised form \\ February, 25, 2011 \\ Accepted 2 April 2012 \\ Available online \\ April 52012 \\ Keywords: \\ Performance evaluation, Balanced \\ ScoreCard (BSC) \\ Fuzzy Decision making trial and \\ evaluation laboratory \\ (DEMATEL) \\ Fuzzy Analytic Network Process \\ (FANP) \\ Fuzzy Analytical Hierarchy \\ Process (AHP) \\ Islamic Azad university of Semnan
}

${ }^{a}$ Assistant Prof., Science and Research Branch, Islamic Azad University, Tehran, Iran

${ }^{b}$ Young Researchers Club, Semnan branch, Islamic Azad University, Semnan, Iran

${ }^{c}$ Instructor, Industrial Safety Engineering Department, Eyvanakey Institute of Higher Education, Semnan, Iran

\begin{abstract}
A B S T R A C T
The success of each organization depends undoubtedly on the quality of its management and management quality depends on decision quality and information quality on the quality of its measurement and proportion. Therefore, its accuracy and measurement has a key role in the success of the organization and the weakness of performance evaluation and managerial control system can transfer to a barrier for the growth of organization. Performance evaluation systems are now dividable to two traditional group (performance evaluation of an individual across reminding him about his performance) and modern group (developing and improving the capacity of evaluated individual and inclined to achievement of organizational objectives and strategies). One of the most authoritative strategic models in this field is the balanced scorecard (BSC) model in which entire aspects of an organization are dominantly investigated. However, no operational trend has been introduced for utilizing it up to now.

In this paper, an operational trend is introduced to apply the foundations of BSC model and multiple criteria decision making (MCDM) techniques. The most important goal of researchers in representation of new structure for creating development and growth capacity and permanent improvement is associated by a kind of providence, such that it can develop desirable organizational and work behaviors towards achieving the objectives and strategies of the organization. In addition, the strategic planning of Islamic Azad university of Semnan was modeled by suggested structure to validate the suggested structure's capacities. The results showed that outputs were more tangible for the personnel of the organization and the results were accepted by the managers of Islamic Azad university of Semnan.
\end{abstract}

\section{Introduction}

One Performance evaluation and measurement of organizational activities have long been the starting point of management scientific processes and the usual issue of researchers and managers discussion (Maltz \& et. al., 2003). The five main duties of management referred to POSDCORB are decelerated as Planning, Organization, Staffing, Directing Co-Ordinating, Reporting and Budgeting in managerial literatures (Gulick \& Urwick, 1973). Therefore, it is considered that performance evaluation and controlling the organization is one of the most important duties of managers, since, if the objectives are measurable, they will be achievable, manageable and controllable (Neely \& Adams, 2000).

* Corresponding author. Tel: +98 9125314901

E-mail addresses: hamid15465@yahoo.com (H. Karkehabadi) 
Performance measurement systems are in fact a part of performance management systems applied as a quantifying measure for efficiency and effectiveness of an activity (Neely Andy \& Platts, 1995). Evans and Lindsay (Evans \& Lindsay, 2005) believe that the use of performance evaluation systems leads in the outbreak of superior features in the organization in this across. Simons (Simons, 2000) considers the performance evaluation and control systems as a factor for achievement of customer expectation.

The related literatures of performance measurement include two orders. In the first order which last until 1930, the focus of performance measurement was placed on provided financial measures by management accounting systems (Lebas, 1995) and the second order begins from late 1980 which is still improving and interest in this field is always increasing, such that many of researchers call this order as performance measurement movement (Baldwin \& Clark, 1992).

Prolific studies (Prowse \& Prowse, 2009; Sole, 2009; Jyoti \& et.al., 2008; Hassab \& et. al. , 2010; Ramstad, 2009; Lester \& et al., 2010; De Waal, 2010; Agrawal, 2008; Cross \& Lynch, 1988; Niven, 2002) examined and compared the performance evaluation systems and their influences on organizations, but about the best model, we can refer to studies (Kaplan \& Norton, 2002; Kaplan \& Norton, 1996) which eventually introduced balanced models such as BSC as the best model for performance evaluation. This model was first introduced by Kaplan and Norton as a modern system in management in 1992 by requirement and needs perception of modern organizations and effective implementation of strategy and creating a comprehensive management system as well as performance improvement. Managerial BSC was declared as a comprehensive framework of performance evaluation and strategy promotion, which leads in creating balance between short term and long term objectives, financial and nonfinancial measures, internal and external performances, inward and outward beneficiaries, ductile indexes and performance function and between strategy motives and barriers (Grigoroudis et al., 2012).

BSC is proved to be a frameworks which describe and operationalize the organization strategy (Makhijani \& Creelman, 2008; Niven, 2006). Therefore, in designing balanced scorecard, the organization has to measure the vital factors, which specify the organization strategy for value creation in long term future (Kaplan \& Norton, 2004). BSC is a management system, which can manage strategy implementation and measure organizational performance in customer, internal processes, growth and learning and financial aspects, and can cause transmission and realization of mission perspective and performance expectations to the external and internal beneficiaries of the organization. In other words, BSC can indicate the mission and vision of the organization in the form of causal relations in the four perspectives (Kaplan \& Norton, 2000; Niven, 2006; Chen \& et al., 2006). In addition, it looks to the organization as an integrated and unified figure (Achterbergh et al., 2003; Nissen, 2006; Blokdijk, 2008). These superior features of BSC are useful in different service and industrial departments (Xu \& Yeh, 2012). According to Makhijani and Creelman (2008) BSC framework is composed of four interrelated component, which are as follows,

A. Strategy map which identify and explain the relation among the strategic objectives after identifying the strategic objectives.

B. Performance measures which indicate the improvement toward the strategic objectives.

C. Quantitative objectives, which are specified for each measures.

D. Selection and implementation of strategic innovations that performance links to quantitative objectives and finally the strategic objectives are achieved.

BSC innovators believe that successful implementation of organization strategy depends on the issue that organizational individuals realize the strategies. It should be mentioned that this affair, in itself require the creation of complicated processes which cause to tangible outputs (Kaplan \& Norton, 
2000). To do so, BSC innovators introduced the strategy map in the first component which can represent the link between the structure of organization strategy by recognizing and deriving organizational (strategic) key objectives and visualizing the cause-effect relations among them (Kaplan \& Norton, 2000). In other words, by considering the strategy map as a basis and foundation for BSC, a pattern is produced where as its innovators declare leads in acceleration of successful implementation of BSC (Makhijani \& Creelman, 2008). For example, there are many studies (Jassbi et al., 2011; Huang et al., 2011; Chang et al., 2011; Cebeci, 2009; Buytendijk et al., 2010; Tohidi et al., 2010a; Tohidi et al. , 2010b), which accelerate the implementation of their scorecard by applying the strategy map.

Different organizations seem that they often select the aspects of strategy map and interpolated strategic objectives proportion to the given framework by the innovators of BSC without considering causal relationships between the strategic objectives and just by senior manager's ideas and consensus as well as expertise and staffs by organizational experience and across numerical management meetings. With respect to reported researches, no certain criteria or approaches are introduced for determining the structure of objectives and key measures of organization as well as creating causal relationships in terms of strategy map (Bukh \& Malmi, 2005). Unfortunately, many organizations and corporations face a lot of problems in their way of BSC implementation since they make serious mistakes in their drawing of strategy map (Makhijani \& Creelman, 2008).

With respect to this problem, by investigation of 12 companies implementing BSC, Quezad et al. (2009) introduced four methods for drawing of strategy map, which are as follow,

Method1: strategic process include mission and vision setting, external and internal analysis (SWOT analysis), which ultimately draws strategy map after strategic goal setting from SWOT analysis. Fig. 1 demonstrates the first method.

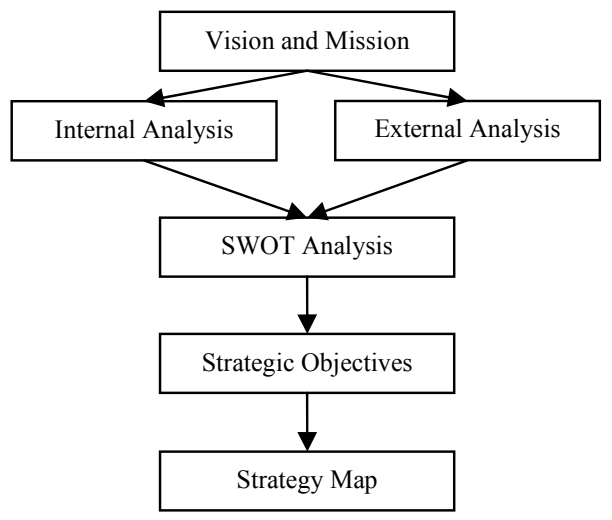

Fig. 1. Method 1 for identifying strategy maps (Quezad et al., 2009)

Method 2: this method is the same as the first one, but the difference is that two kinds of objectives, general and strategic objectives, are set. General objectives are directly set from mission and vision, while strategic objectives are driven from SWOT analysis. The advantage of this method compared with the first one is that it can convert the mission and vision to total objectives and contributes to the organizations in defining strategic directions in strategy map. Fig. 2 is the indicator of the second method. 


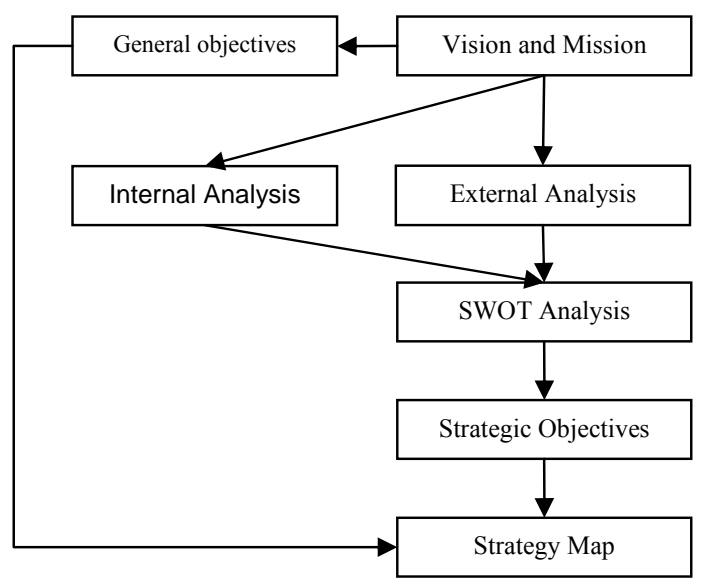

Fig. 2. Method 2 for defining strategic objectives (Quezad \& et. al., 2009)

Method3: Strategic themes of organizational missions and visions, which are the bases for strategic goal setting are defined in this method. Fig. 3 indicates the strategic goal setting process according to the third method. One of the main deficiencies of this method is that expression of mission and vision builds organizational general ways, therefore, creation of strategy map, which in fact lead to the achievement of organizational strategy might be ambiguous.

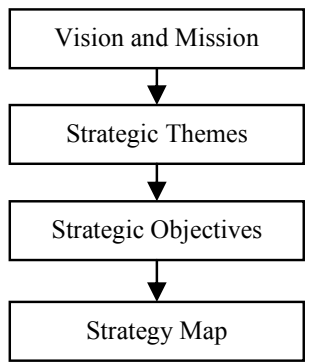

Fig. 3. Method 3 for defining strategic objectives (Quezad \& et. al., 2009)

Method4: this method is a compilation of the second and the third one which is dominant in the fourth method.

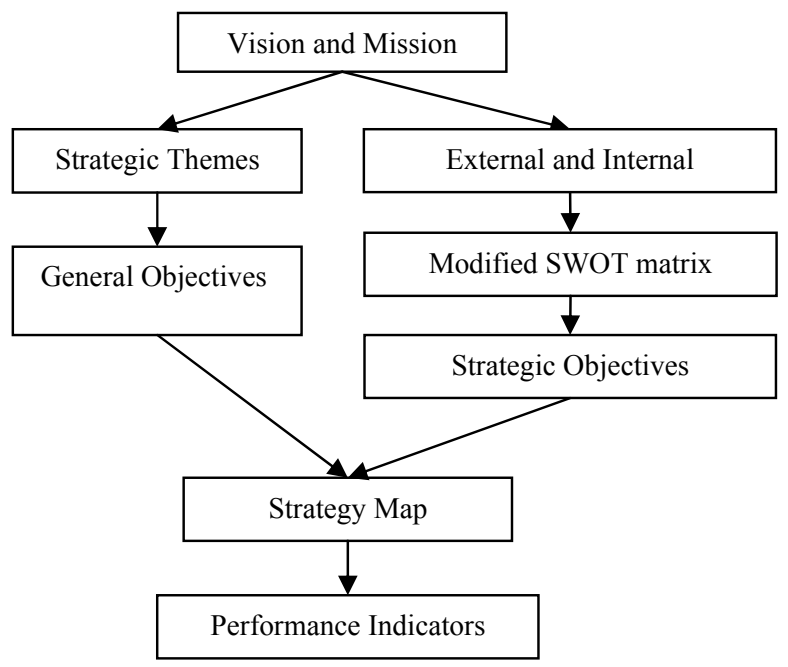

Fig. 4. Method 4 for Generation of strategic objectives (Quezad et al., 2009) 
The fourth method is introduced as the best method in this paper, which could enjoy of the whole strength and advantages of the previous methods (Quezad et al., 2009).

However, as it is obvious, no point is expressed about how relations are set among them in the $4^{\text {th }}$ Fig. In this respect, one can refer to studies such as Seyed-hosseini et al. (2011) and Jassbi et al. (2011) which have tried to solve this problem by application of DEMATEL technique. The relationships are defined in their studies by investigation of map components (strategic objectives) from expert's point of view and without considering the relational levels among macro objectives and strategic goals by the use of fuzzy DEMATEL technique.

BSC innovators tried to quantify the strategy levels by introducing performance measures and quantitative objectives to transfer the organizational intangible assets and investments to tangible outputs in the second and third components. Finally, they have referred to strategic innovations in the last components for creation of relationship between performance and quantitative objectives (Bunker et al., 2004; Ravi et al., 2005; Stwart \& Mohamed, 2001; Clinton et al., 2002; Sohn et al., 2003; Chiang, 2005; Lee et al., 2008; Wu et al., 2009; Oh et al., 2009). Note that in order to use MCDM techniques, we need to apply a method to prioritize them (Yan \& Chang-Hsing, 2012).

Therefore, by considering the problems and shortcomings of previous studies, this paper tries to cover the weakness of the previous models and the proposed model is implemented in Islamic Azad university of Semnan.

\section{Methodology}

In this section, we consider a set of activities performed for implementing a successful performance evaluation system based on BSC in conceptual model to modify and improve the previous plans, which would be given separately in four designing, goal setting, performance evaluation and result description sections.

\subsection{Section one: Designing}

The designing section is aimed to describe concepts such as strategic themes, macro objectives, strategic objectives and finally strategic map by creating an appropriate platform.

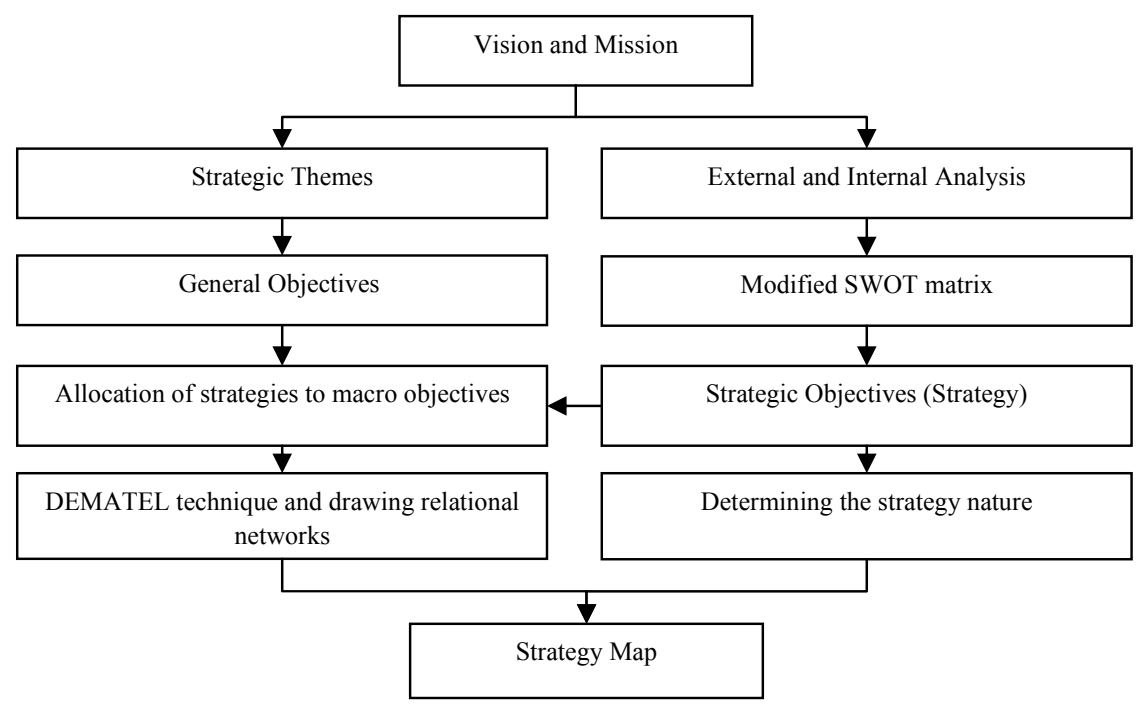

Fig. 5. A surface of the administrative trend of designing section 
For raising this goal by utilizing the method given by Quezad et al. (2009) (Fig. 4) and the results presented by Seyed-hosseini et al. (2011) and Jassbi et al. (2011) and performing modification, A framework similar to the Fig. 5 is suggested.

2.1.1. Vision and mission: mission and vision statement determine the main objectives and direction of the organization. The organization should describe how and why is present in business environment.

2.1.2. The strategic themes: the important processes which are significant for creation and representation of different value to customer should be defined in this stage by considering the organization mission and vision.

2.1.3. Macro objectives: macro objectives are derived from strategic themes. We can define one or more macro objective for each strategic theme.

2.1.4. Environmental analysis and SWOT matrix: This step is suggested for investigating the internal strength and weaknesses and external opportunities and threats for derivation of expected strategies in future by the use of SWOT matrix.

2.1.5. Strategic objectives: these objectives are obtained by analyzing strength, weaknesses, opportunities and threats, which are done in SWOT matrix.

2.1.6. Allocation of strategic to macro objectives: In this step we investigate the relational levels between macro objectives and strategic objectives by the help of expert group. The aim of suggesting this step is separation of the strategies to homogeneous groups, which increase the accuracy in identification and determination of reciprocal relations.

2.1.7. Determination of strategy nature: in this level, the strategies are categorized in BSC aspects by the aid of expert group and BSC specialists. This step can be regarded as a basis for drawing the organization strategy map.

2.1.8. DEMATEL technique and drawing relational networks: with regard to the given division for the strategic objectives (categorization 2.1.6), we pay to measure the severity of relations among strategies by fuzzy DEMATEL technique. (For being familiar with foundation of fuzzy DEMANTEL, references (Wu \& Lee, 2007; Tseng, 2010; Chang et al., 2011; Jassbi et al., 2011; Lee et al., 2011; Zhou et al., 2011) are suggested).

2.1.9. Strategy map: the strategy map is drawn in this step by incorporation of obtained networks from 2.1.8.

\subsection{The second section: Goal setting}

The goal setting section aims to produce tangible objectives for organizational personnel and proctors by creating a few quantities of strategic planning theory concepts. Fig. 6 visualizes a surface of goal setting section.

2.2.1. Performance indexes: performance indexes will be identified as the indicators of short-term objectives for organization in order to achieve long term objectives in this step. It is suggested that 
performance indexes to be derived from constructing components of strategy map (strategic objectives) in order to exist enough universality in performance measurement.

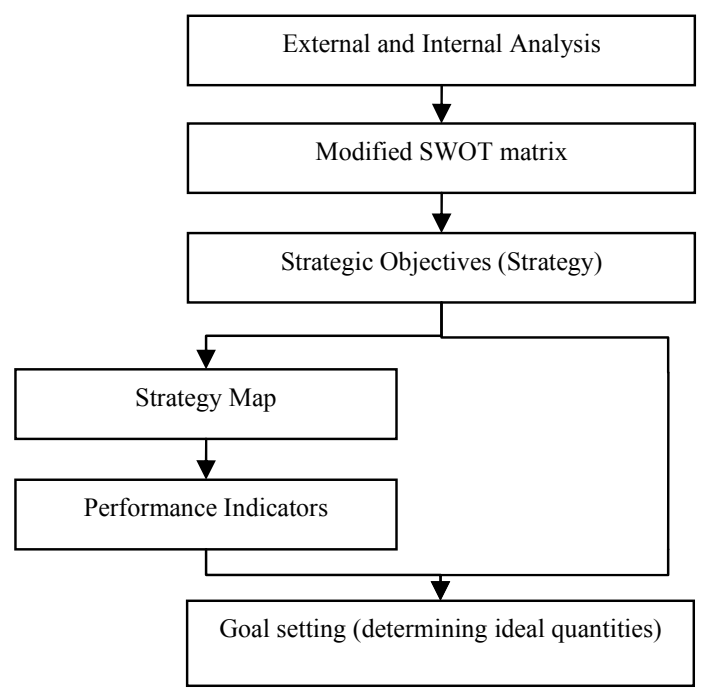

Fig. 6. A surface of administrative trend of goal setting section

2.2.2. Goal setting (determining ideal quantities): The ideal quantities of performance indexes are derived with regard to strategic objectives in this step by the assistance of organization experts and previous recorded information.

\subsection{The third section: performance evaluation}

The performance evaluation section aims to identify the performance gap by calculating the organization performance quantity in an especial period. The Fig. 7 indicates a surface of performance evaluation.

2.3.1. Derivation of strategy map components weight matrix (strategic goals) by fuzzy DEMATEL technique: a limit super matrix will be obtained in this step by considering the total relationships matrix of fuzzy DEMATEL technique as a non-weighted super matrix and use of fuzzy ANP technique (for familiarity with foundations of fuzzy ANP technique, the references (Chen \& Chen, 2010; Kuoa \& Liang, 2011; Sevkli et al., 2012; Hsu et al., 2012; Özkır \& Demirel, 2012) are suggested), which is suggested as the weighted matrix of strategy map components.

2.3.2. Derivation of weighted matrix of indexes by the use of fuzzy AHP technique: a proper weight is considered for indexes according to basis of fuzzy AHP technique in this step by suggesting the pair comparison of indexes with separation of strategic objectives (For familiarity with foundations of fuzzy AHP technique, references (Zheng et al., 2012; Javanbarg et al., 2012; Wang et al., 2012; Bulut et al., 2012) are suggested).

2.3.3. Derivation of status que quantities: some quantities are regarded for performance indexes in this step according to environmental analysis; these quantities are suggested as a basis for indicating the scale of goal achievement in organization (the proportion of status que quantities to ideal quantities). 


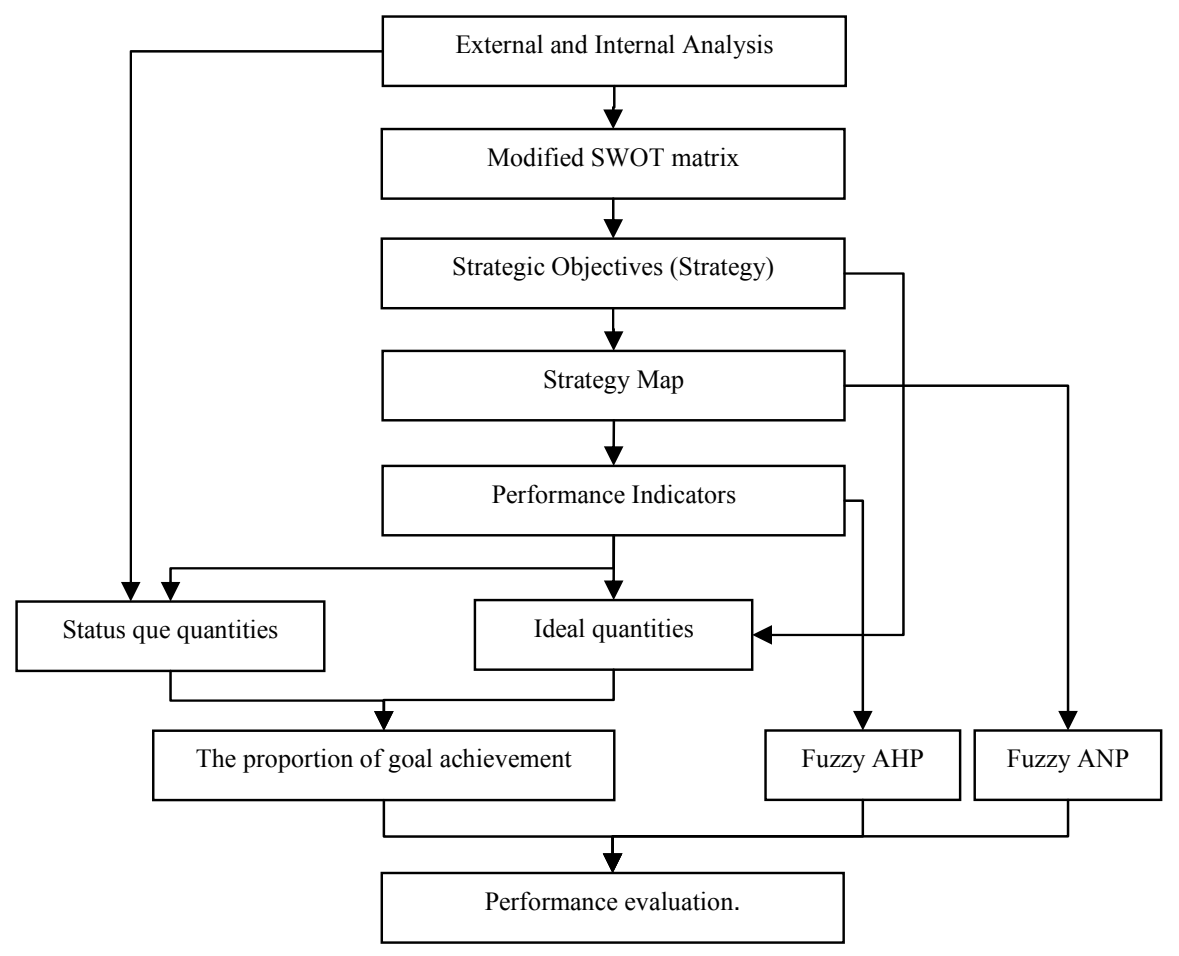

Fig. 7. A surface of administrative trend of performance evaluation section

2.3.4. Performance evaluation: quantities are obtained for each index by comparable multiple of strategies weighted quantities, performance indexes and the quantity of goal achievement (the proportion of status que quantities to ideal quantities) which by summation of quantities of all indexes, a quantity between zero and one will be obtained which is the indicator of organization performance quantity.

\subsection{The fourth section: result description}

The result description section is aimed to provide a proper position for organization staff for future decision making of organization by the aim of decreasing performance gaps and goal achievement by creating desire division and drawing required diagrams. It should be mentioned that the result description section can be associated by researcher's creativity in divisions and diagrams.

\section{Analyzing the suggested method in Islamic Azad university of Semnan}

3.1 The first step of the first section (designing section) - mission and vision statement: The mission of Islamic Azad University as a nonprofit organization is extension and promotion of knowledge, skill and fostering innovative and thoughtful people in different fields of science and technology under promoting the quality of college life. In addition, it considers one of its duties as an appropriate accountable organization to different educational expectations of society and its beneficiaries with enhancing the educational services. Islamic Azad University as a great and reliable scientific centre in state level has the responsibility to promote welfare level and economic, social and cultural growth of society and production and issuance of science.

Vision statement of Islamic Azad University existed for the year 2025. Based on this resolution, Islamic Azad University, which is entrepreneur and effective in economic growth of the state, superior in presenting educational services to different classes of society, vanguard in producing science, theory and thoughts in southwest Asia, equipped with improved research centers based on 
international standards, responsible for new expectations of society and well known in international reliable communities in which alumnus will build the future human society.

3.2. The second step of the first section (designing section) - defining the strategic themes: the following Strategic Themes (Table1) are obtained by considering the mission and vision of Islamic Azad University of Semnan.

\section{Table 1}

University strategic implications

1 entrepreneurship and effectiveness in country economic development and growth

2 representation of different research and education services to different research and education services to different classes of society and vanguard in science production

3 accountability to new exception of society and scientific conventions

3.3. The third step of section (designing section) - determining General objectives: with respect to organization strategic implications and strategic team, General objectives are identified and stated in Table 2.

Table 2

General objectives of Islamic Azad university of Semnan

\begin{tabular}{|c|c|}
\hline Strategic Themes & General Objectives \\
\hline $\begin{array}{l}\text { entrepreneurship and effectiveness in } \\
\text { country economic development and } \\
\text { growth }\end{array}$ & $\begin{array}{l}\mathrm{O}_{1} \text { : It can improve the efficient and effective relations with } \\
\text { industries for financial dependence on student's fee by increasing } \\
\text { hardware and software capabilities. }\end{array}$ \\
\hline $\begin{array}{l}\text { representation of different research and } \\
\text { education services to different research } \\
\text { and education services to different } \\
\text { classes of society and vanguard in } \\
\text { science production }\end{array}$ & $\begin{array}{l}\mathrm{O}_{2} \text { : Creating an efficient system of intellectual and moral ownership } \\
\text { for the sale of scientific patents. } \\
\mathrm{O}_{3} \text { : Developing and equipping in order to promoting the university } \\
\text { at least in one of the introduced scientific educational field in the } \\
\text { country. } \\
\mathrm{O}_{4} \text { : Creating and equipment of the growth centers for converting the } \\
\text { scientific results to saleable scientific patents. }\end{array}$ \\
\hline $\begin{array}{l}\text { accountability to new exception of } \\
\text { society and scientific conventions }\end{array}$ & $\begin{array}{l}\mathrm{O}_{5}: \text { IT application and its institutionalization in key processes of the } \\
\text { university. } \\
\mathrm{O}_{6} \text { : Creation of incentive points for development of software } \\
\text { capitals (human for enabling the staffs and faculty members in } \\
\text { universities) }\end{array}$ \\
\hline
\end{tabular}

3.4. The fourth and fifth steps of the first section (designing section) - internal and external analysis and determining the strategic objectives: the SWOT matrix of Semnan Islamic Azad university is described as Table 3.

3.5. The sixth step of the first section (designing section) - allocation of strategic objectives to General objectives: with respect to General objectives of the second Table and strategic objectives of the third table, the communicational levels between General objectives and strategic objectives was derived according to homogeneous groups of the fourth Table 4.

3.6 The seventh step of the first section (designing section) - determining strategy nature: the university strategies are categorized in BSC aspects according to Table 5 based on expert group ideas and balanced scorecard specialists. 
Table 3

University SWOT matrix

\begin{tabular}{|c|c|c|}
\hline & Strengths and & Weaknesses \\
\hline Opportunities and Threats & $\begin{array}{l}\text { Strengths } \\
\text { 1. Significant growth of innovation } \\
\text { registration in universities in current years. } \\
\text { 2. Coordination of workshop, laboratory } \\
\text { and survey facilities with professors and } \\
\text { student's needs. } \\
\text { 3. Possibility of applying the existing } \\
\text { faculty boards for establishing } \\
\text { interdisciplinary fields. }\end{array}$ & $\begin{array}{l}\text { Weaknesses } \\
\text { 1. Disproportion of pyramid structure of } \\
\text { faculty board } \\
\text { 2. Disproportion of pyramid structures } \\
\text { of educational and investigational fields } \\
\text { 3. Non mastery of deserve democracy in } \\
\text { jobs } \\
\text { 4. Deficiency of financial resources. } \\
\text { And ... }\end{array}$ \\
\hline $\begin{array}{l}\text { Opportunities } \\
\text { 1. Developing the possibility of higher } \\
\text { education in different fields with respect } \\
\text { to pyramid variation of educational grade } \\
\text { and the ever growth of entry volunteers } \\
\text { for higher education. } \\
\text { 2. Change of consumption pattern and } \\
\text { positive attitude of society to education } \\
\text { and scientific centers orientation to } \\
\text { research and science production. } \\
\text { And ... }\end{array}$ & $\begin{array}{l}\mathrm{S}_{1} \text {. Identifying thee applied fields in survey } \\
\text { scientific communities of the country. } \\
\mathrm{S}_{2} \text {. developing the applied fields } \\
\mathrm{S}_{3} \text {. Creation and development of technology } \\
\text { and growth centers } \\
\mathrm{S}_{4} \text {. Enhancement of the research activities } \\
\text { shares of universities in reliable survey } \\
\text { scientific communities of the country. }\end{array}$ & $\begin{array}{l}\mathrm{S}_{5} \text {. Effective information and relations } \\
\text { with industries } \\
\mathrm{S}_{6} \text {. Developing equipment (enhancing } \\
\text { hardware power) } \\
\mathrm{S}_{7} \text {. Developing creativity and innovative } \\
\text { culture in students and professors }\end{array}$ \\
\hline $\begin{array}{l}\text { Threats } \\
\text { 1. Applied new technologies by } \\
\text { competitors } \\
\text { 2. Related regulation of giving equal } \\
\text { opportunities to university graduated for } \\
\text { providing job } \\
\text { 3. Tying the higher education growth to } \\
\text { employment } \\
\text { 4. Increasing the capacity of the state and } \\
\text { nonprofit universities }\end{array}$ & $\begin{array}{l}\mathrm{S}_{8} \text {. Developing the university brand } \\
\mathrm{S}_{9} \text {. Enhancing the sale of scientific patents } \\
\mathrm{S}_{10} \text {. Enhancing the efficiency and security of } \\
\text { information exchange } \\
\mathrm{S}_{11} \text {. efficiency enhancement for reducing the } \\
\text { service price of university } \\
\mathrm{S}_{12} \text {. Enhancing the competitive advantages } \\
\text { of university in proportion to other } \\
\text { competitors }\end{array}$ & $\begin{array}{l}\mathrm{S}_{13} \text {. Updating the job training and } \\
\text { empowerment of scientific boards } \\
\text { (software power enhancement of } \\
\text { university) } \\
\mathrm{S}_{14} \text {. Creating an independent and } \\
\text { powerful legal system for university } \\
\mathrm{S}_{15} \text {. Promotion of organizational culture } \\
\mathrm{S}_{16} \text {. IT development and its application in } \\
\text { university } \\
\mathrm{S}_{17} \text {. Enforcing the incentive points of } \\
\text { human force }\end{array}$ \\
\hline
\end{tabular}

Table 4

Communicational levels between General objectives and strategic objectives General Objectives

\begin{tabular}{|c|c|c|c|c|c|c|}
\hline Strategic Objectives & $\begin{array}{l}\text { O1. It can } \\
\text { improve the } \\
\text { efficient .... }\end{array}$ & $\begin{array}{l}\text { O2. Creating an } \\
\text { efficient system } \\
\ldots\end{array}$ & $\begin{array}{l}\text { O3. Developing } \\
\text { and equipping in } \\
\text { order to... }\end{array}$ & $\begin{array}{l}\text { O4. Creating } \\
\text { and equipment } \\
\text { of the... }\end{array}$ & $\begin{array}{l}\text { O5. IT } \\
\text { application and } \\
\text { its ... }\end{array}$ & $\begin{array}{l}\text { O6. Creation of } \\
\text { incentive points } \\
\text { for ... }\end{array}$ \\
\hline $\mathrm{S}_{1}$. Identifying thee ... & & & $\sqrt{ }$ & & & \\
\hline $\mathrm{S}_{2}$. Developing the ... & & & $\sqrt{ }$ & & & \\
\hline $\mathrm{S}_{3}$. Creation and ... & $\sqrt{ }$ & & & $\sqrt{ }$ & & \\
\hline $\mathrm{S}_{4}$. Enhancement of ... & & & $\sqrt{ }$ & & & \\
\hline $\mathrm{S}_{5}$. Effective $\ldots$ & $\sqrt{ }$ & & & & & \\
\hline $\mathrm{S}_{6}$. Developing ... & & & $\sqrt{ }$ & $\sqrt{ }$ & $\sqrt{ }$ & \\
\hline $\mathrm{S}_{7}$. Developing ... & $\sqrt{ }$ & & & & & \\
\hline $\mathrm{S}_{8}$. Developing the ... & $\sqrt{ }$ & & & & & $\sqrt{ }$ \\
\hline $\mathrm{S}_{9 .}$ Enhancing the ... & $\sqrt{ }$ & $\sqrt{ }$ & & $\sqrt{ }$ & & \\
\hline $\mathrm{S}_{10}$. Enhancing the $\ldots$ & & & & & $\sqrt{ }$ & \\
\hline $\mathrm{S}_{11}$. Efficiency ... & & & & & $\sqrt{ }$ & \\
\hline $\mathrm{S}_{12}$. Enhancing the ... & & & & & $\sqrt{ }$ & $\sqrt{ }$ \\
\hline $\mathrm{S}_{13}$. Updating the job ... & $\sqrt{ }$ & & $\sqrt{ }$ & & & \\
\hline $\mathrm{S}_{14 .}$ Creating an $\ldots$ & & $\sqrt{ }$ & & & & \\
\hline $\mathrm{S}_{15}$. Promotion of ... & & $\sqrt{ }$ & & & & \\
\hline $\mathrm{S}_{16}$. IT development ... & & & & & $\sqrt{ }$ & \\
\hline $\mathrm{S}_{17}$. Enforcing the $\ldots$ & & & & & & $\sqrt{ }$ \\
\hline
\end{tabular}


Table 5

University strategies by separation of Balanced scorecard's perspectives

\begin{tabular}{|c|c|}
\hline $\begin{array}{l}\text { Balanced scorecard`s } \\
\text { perspectives }\end{array}$ & strategies \\
\hline Customer and scientific credits & $\begin{array}{l}\mathrm{S}_{4} \text {. Enhancement of the research activities shares of universities in reliable } \\
\text { survey scientific communities of the country. } \\
\mathrm{S}_{8} \text {. Developing the university brand }\end{array}$ \\
\hline Financial & $\begin{array}{l}\mathrm{S}_{9} . \text { Enhancing the sale of scientific patents } \\
\mathrm{S}_{11} \text {.efficiency enhancement for reducing the service price of university }\end{array}$ \\
\hline Internal Processes & $\begin{array}{l}\mathrm{S}_{5} \text {. Effective information and relations with industries } \\
\mathrm{S}_{6} \text {. Developing equipment (enhancing hardware power) } \\
\mathrm{S}_{14} \text {. Creating an independent and powerful legal system for university } \\
\mathrm{S}_{10} \text {. Enhancing the efficiency and security of information exchange } \\
\mathrm{S}_{2} \text {. developing the applied fields } \\
\mathrm{S}_{3} \text {. Creation and development of technology and growth centers }\end{array}$ \\
\hline Learning & $\begin{array}{l}\mathrm{S}_{16} \text {. IT development and its application in university } \\
\mathrm{S}_{17} \text {. Enforcing the incentive points of human force } \\
\mathrm{S}_{12} \text {. Enhancing the competitive advantages of university in proportion to } \\
\text { other competitors } \\
\mathrm{S}_{13} \text {. Updating the job training and empowerment of scientific boards } \\
\text { (software power enhancement of university) } \\
\mathrm{S}_{15} \text {. Promotion of organizational culture } \\
\mathrm{S}_{1} \text {. Identifying thee applied fields in survey scientific communities of the } \\
\text { country. } \\
\mathrm{S}_{7} \text {. Developing creativity and innovative culture in students and professors }\end{array}$ \\
\hline
\end{tabular}

3.7. The eighth step of the first section (designing section) - DEMATEL technique and drawing communicational network: relation diagraph was derived by the use of fuzzy DEMATEL technique in this step with respect to performed division in the Table 6.

3.8 The ninth step of the first section (designing section) - drawing the strategy map: the attention is paid to drawing the strategy map by incorporation of Table 6 diagraphs in this. Step and the results of existing diagram will be on the $7^{\text {th }}$ Table.

3.9 The second section (goal setting section): performed initiations about this section are described as two performance indexes and goal setting steps, which are orderly indicated in the $4^{\text {th }}$ and $6^{\text {th }}$ columns of Table 8.

3.10 The third section (performance evaluation section): in order to reach goal achievement, this section considers 4 steps as derivation of strategy map components weighted matrix, derivation of indexes weighted matrix, derivation of status que quantities and performance evaluation. The result about Semnan Islamic Azad university are orderly observed in the $3 \mathrm{rd}$, the $5^{\text {th }}$, the $7^{\text {th }}$ and the $8^{\text {th }}$ columns of Table 8 .

3.11 The fourth section (result description section): the results are provided in three categorizations in the form of BSC, macro objectives and strategic objectives.

3.11.1 Result description by description of BSC aspects: by the summation of strategic objectives quantities by the separation of balanced scorecard, the results of the second Table 9 and diagram 1 
will be derived. The results in this section show that Semnan Islamic Azad University has the minimum performance gap in financial activities and the maximum in learning and growth activities.

\section{Table 6}

The influence diagraph of strategies on each other by separation of homogeneous groups

\begin{tabular}{|c|c|c|}
\hline Explanation of General Objectives & $\begin{array}{l}\text { Strategies } \\
\end{array}$ & $\begin{array}{c}\text { Graphs of strategies effects on each } \\
\text { (obtained from fuzzy DEMATEL technique) }\end{array}$ \\
\hline $\begin{array}{l}\text { O1. It can improve the efficient } \\
\text { and effective relations with industries } \\
\text { for financial dependence on student's } \\
\text { fee by increasing hardware and } \\
\text { software capabilities. }\end{array}$ & $\begin{array}{l}\text { S. Creation and development of technology } \\
\text { and growth centers } \\
\text { S4. Enhancement of the research activities } \\
\text { shares... } \\
\text { S5. Effective information and relations with } \\
\text { industries } \\
\text { S7. Developing creativity and innovative } \\
\text { culture in students and professors } \\
\text { S8. Developing the university brand } \\
\text { S9. Enhancing the sale of scientific patents } \\
\text { S13. Updating the job training and } \\
\text { empowerment of scientific boards }\end{array}$ & ( \\
\hline $\begin{array}{l}\text { O2. Creating an efficient system of } \\
\text { intellectual and moral ownership for } \\
\text { the sale of scientific patents. }\end{array}$ & $\begin{array}{l}\mathrm{S}_{9 .} \text {. Enhancing the sale of scientific patents } \\
\mathrm{S}_{14 .} \text { Creating an independent and powerful } \\
\text { legal system for university } \\
\mathrm{S}_{15} \text {. Promotion of organizational culture }\end{array}$ & $\mathrm{S} 15$ \\
\hline $\begin{array}{l}\text { O3. Developing and equipping in } \\
\text { order to promoting the university at } \\
\text { least in one of the introduced } \\
\text { scientific educational field in the } \\
\text { country. }\end{array}$ & $\begin{array}{l}\mathrm{S}_{1} \text {. Identifying thee applied fields in survey } \\
\text { scientific communities of the country. } \\
\mathrm{S}_{2} \text {. Developing the applied fields } \\
\mathrm{S}_{4} \text {. Enhancement of the research activities } \\
\text { shares of universities in ... } \\
\mathrm{S}_{6} \text {. Developing ... } \\
\mathrm{S}_{13} \text {. Updating the job ... }\end{array}$ & \$6 \\
\hline $\begin{array}{l}\text { O4. Creating and equipment of the } \\
\text { growth centers for converting the } \\
\text { scientific results to saleable scientific } \\
\text { patents. }\end{array}$ & $\begin{array}{l}\mathrm{S}_{3 .} \text { Creation and development of technology } \\
\text { and growth centers } \\
\mathrm{S}_{6} \text {. Developing ... } \\
\mathrm{S}_{9} \text {. Enhancing the sale of scientific patents }\end{array}$ & $\begin{array}{l}7 \\
\text { s3 }\end{array}$ \\
\hline $\begin{array}{l}\text { O5. IT application and its } \\
\text { institutionalization in key processes } \\
\text { of the university. }\end{array}$ & $\begin{array}{l}\mathrm{S}_{6 .} \text {. Developing } \ldots . \\
\mathrm{S}_{10} \text {. Enhancing the } \ldots \\
\mathrm{S}_{11} \text {.efficiency .... } \\
\mathrm{S}_{12} \text {. Enhancing the ... } \\
\mathrm{S}_{16 .} \text { IT development ... }\end{array}$ & \\
\hline $\begin{array}{l}\text { O6. Creation of incentive points for } \\
\text { development of software capitals } \\
\text { (human for enabling the staffs and } \\
\text { faculty members in universities) }\end{array}$ & $\begin{array}{l}\mathrm{S}_{8} \text {. Developing the university brand } \\
\mathrm{S}_{12} \text {. Enhancing the competitive advantages } \\
\ldots \\
\mathrm{S}_{17} \text {. Enforcing the incentive points of } \ldots\end{array}$ & $\begin{array}{l}1 \\
S 12\end{array}$ \\
\hline
\end{tabular}


3.11.2. Result description by describing macro objectives: the results of the $10^{\text {th }}$ Table and diagram 2 will be derived by the summation of strategic objectives quantities by the separation of macro objectives. The results of this section show that Semnan Islamic Azad university has the minimum performance gap in the second macro objective (creation of efficient system of spiritual and conceptual ownership for the sale of scientific) and the maximum in the first macro objective (the section and improvement of efficient and effective communications with industries for decreasing financial dependence on student fee by increasing the software and hardware capabilities).

3.11.3. Result description by describing strategic objectives: The results of the $11^{\text {th }}$ Table and diagram 3 will be derived by the separation of strategic objective. The results in this section show that Semnan Islamic Azad University has the minimum performance gap in the $16^{\text {th }}$ strategic objective (IT development and its application in university) and the maximum in the $10^{\text {th }}$ strategic objective (Increase in efficiency and security in information exchange).

Table 7

The university strategy map

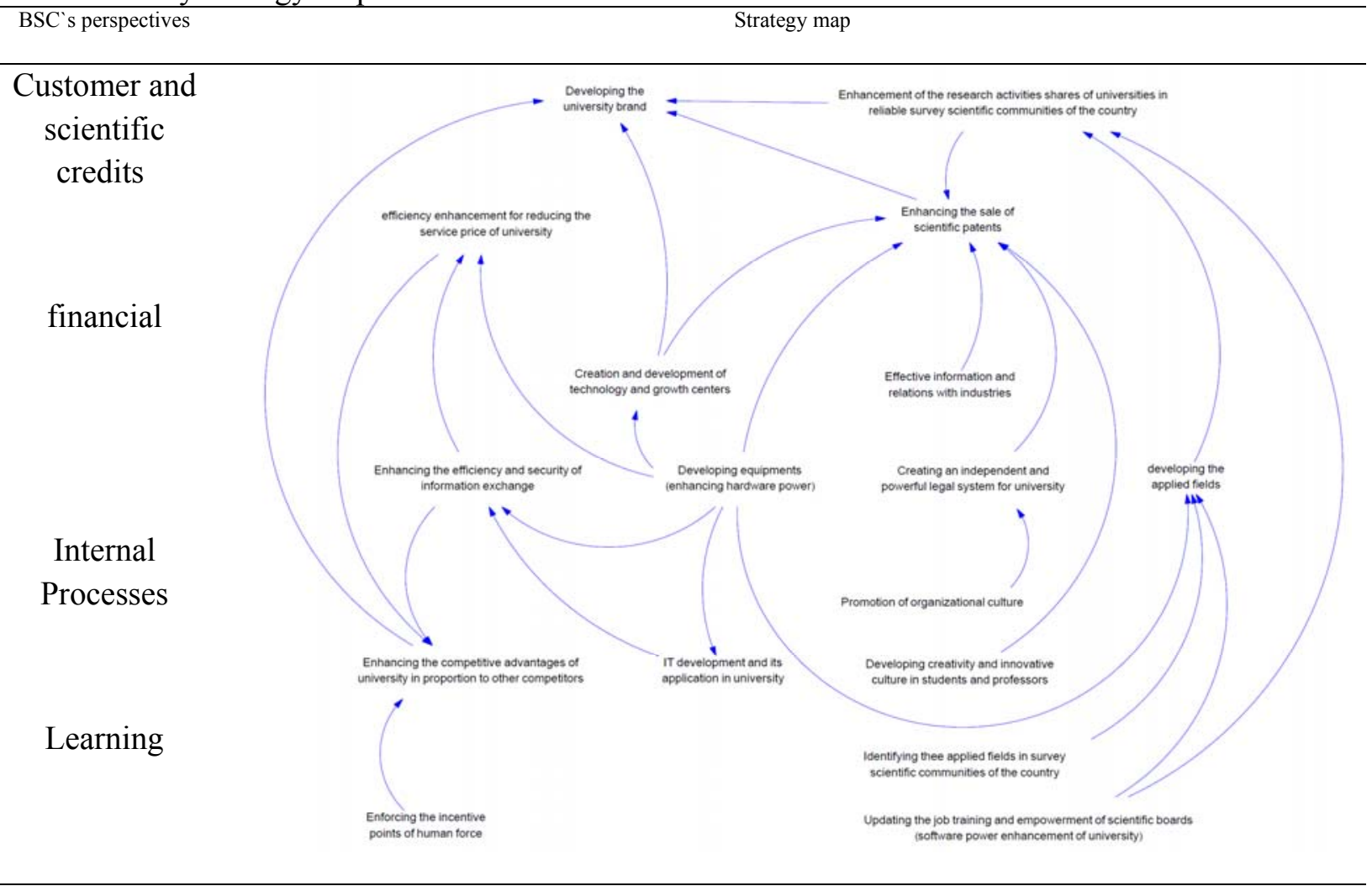


Table 8

Information analysis of Semnan Islamic Azad University in two goal setting and performance evaluation sections

\begin{tabular}{|c|c|c|c|c|c|c|c|}
\hline \multirow[b]{2}{*}{ Perspectives } & \multirow{2}{*}{$\begin{array}{l}\text { Strategic objectives } \\
\text { name }\end{array}$} & \multicolumn{6}{|c|}{ Performance indexes } \\
\hline & & $\begin{array}{l}\text { Weight } \\
\text { (obtained from } \\
\text { fuzzy ANP } \\
\text { technique) }\end{array}$ & name & $\begin{array}{l}\text { Weight } \\
\text { (obtained from } \\
\text { fuzzy AHP } \\
\text { technique) }\end{array}$ & $\begin{array}{c}\text { ideal } \\
\text { quantities }\end{array}$ & $\begin{array}{l}\text { Status que } \\
\text { quantities }\end{array}$ & $\begin{array}{l}\text { Performance } \\
\text { evaluation }\end{array}$ \\
\hline \multirow{7}{*}{$\begin{array}{l}\text { Customer and } \\
\text { scientific credits }\end{array}$} & $\begin{array}{l}\mathrm{S}_{4} \text {. Enhancement of the research } \\
\text { activities shares of universities in } \\
\text { reliable survey scientific communities } \\
\text { of the country. }\end{array}$ & 0.0404 & research scores & 1 & 1000 & 379 & 0.0153 \\
\hline & \multirow{6}{*}{$\mathrm{S}_{8}$. Developing the university brand } & \multirow{6}{*}{0.1603} & industry satisfaction (Wu et al., 2011; Tseng, 2010) & 0.183 & 9 & 2 & 0.0065 \\
\hline & & & students satisfaction & 0.143 & 9 & 1 & 0.0025 \\
\hline & & & customer loyalty(Wu et al., 2011) & 0.169 & 9 & 1 & 0.003 \\
\hline & & & student loyalty & 0.114 & 9 & 4 & 0.0081 \\
\hline & & & university rank in science administration ranking & 0.191 & 20 & $\begin{array}{l}\text { no place in } \\
\text { the ranking }\end{array}$ & 0 \\
\hline & & & Revenues & 0.2 & 1 & 0.85 & 0.0273 \\
\hline \multirow{2}{*}{ Financial } & $\begin{array}{l}\mathrm{S}_{9} . \text { Enhancing the sale of scientific } \\
\text { patents }\end{array}$ & 0.1056 & The number of sold scientific patents. & 1 & 20 & 10 & 0.0528 \\
\hline & $\begin{array}{l}\mathrm{S}_{11} \text {. efficiency enhancement for reducing } \\
\text { the service price of university }\end{array}$ & 0.0447 & the service cost (equipment productivity) ( Tseng, 2010) & 1 & $0.10 \%$ & $2 \%$ & 0.0022 \\
\hline \multirow{8}{*}{ Internal Processes } & \multirow{2}{*}{$\begin{array}{l}\mathrm{S}_{5} . \text { Effective information and relations } \\
\text { with industries }\end{array}$} & \multirow[t]{2}{*}{0.0391} & $\begin{array}{l}\text { the number of agreements, contracts or foreign } \\
\text { organizations }\end{array}$ & 0.311 & 12 & 2 & 0.002 \\
\hline & & & The percentage of research production customers. & 0.689 & $100 \%$ & $10 \%$ & 0.0027 \\
\hline & \multirow{2}{*}{$\begin{array}{l}\mathrm{S}_{6} . \text { Developing equipment (enhancing } \\
\text { hardware power) }\end{array}$} & \multirow[t]{2}{*}{0.0689} & The monetary value of assets & 0.308 & 1 & 0.52 & 0.011 \\
\hline & & & civil space (square meter) & 0.692 & 80000 & 38987 & 0.0232 \\
\hline & $\begin{array}{l}\mathrm{S}_{14} \text {. Creating an independent and } \\
\text { powerful legal system for university }\end{array}$ & 0.0211 & $\begin{array}{l}\text { The number of independent and empowered legal centers } \\
\text { in university }\end{array}$ & 1 & 2 & 1 & 0.0106 \\
\hline & $\begin{array}{l}\mathrm{S}_{10} . \text { Enhancing the efficiency and } \\
\text { security of information exchange }\end{array}$ & 0.0604 & $\begin{array}{l}\text { Application of standard administrative methods in } \\
\text { university(Wu et.al., 2011) }\end{array}$ & 1 & 2 & 0 & 0 \\
\hline & $\mathrm{S}_{2}$. developing the applied fields & 0.0838 & $\begin{array}{l}\text { The rate of given new and functional service/educational } \\
\text { package in every year (Tseng, 2010). }\end{array}$ & 1 & $10 \%$ & $0.50 \%$ & 0.0042 \\
\hline & $\begin{array}{l}\mathrm{S}_{3} \text {. Creation and development of } \\
\text { technology and growth centers }\end{array}$ & 0.0512 & The number of technology and growth centers & 1 & 3 & 1 & 0.0171 \\
\hline
\end{tabular}


Table 8 (Cont.)

Information analysis of Semnan Islamic Azad University in two goal setting and performance evaluation sections

\begin{tabular}{|c|c|c|c|c|c|c|c|}
\hline \multirow[b]{2}{*}{ Perspectives } & \multicolumn{2}{|l|}{ Strategic objectives } & \multicolumn{4}{|c|}{ Performance indexes } & \multirow[b]{2}{*}{$\begin{array}{l}\text { Performance } \\
\text { evaluation }\end{array}$} \\
\hline & name & $\begin{array}{l}\text { Weight } \\
\text { (obtained from } \\
\text { fuzzy ANP } \\
\text { technique) }\end{array}$ & name & $\begin{array}{c}\text { Weight } \\
\text { (obtained from } \\
\text { fuzzy AHP } \\
\text { technique) }\end{array}$ & $\begin{array}{c}\text { ideal } \\
\text { quantities }\end{array}$ & $\begin{array}{l}\text { Status que } \\
\text { quantities }\end{array}$ & \\
\hline \multirow{18}{*}{ Learning } & \multirow{4}{*}{$\begin{array}{l}\text { S16. IT development and its application } \\
\text { in university }\end{array}$} & \multirow{4}{*}{0.0442} & The capacity of university communicational networks & 0.396 & $20 \mathrm{MB}$ & $8 \mathrm{MB}$ & 0.007 \\
\hline & & & Network security & 0.267 & $100 \%$ & $60 \%$ & 0.0071 \\
\hline & & & The number of updated computers & 0.045 & $80 \%$ & $50 \%$ & 0.0012 \\
\hline & & & Number of servers & 0.292 & 8 & 8 & 0.0129 \\
\hline & \multirow{3}{*}{$\begin{array}{l}\text { S17. Enforcing the incentive points of } \\
\text { human force }\end{array}$} & \multirow{3}{*}{0.0385} & $\begin{array}{l}\text { The extent of courage and awards in organization(Wu \& } \\
\text { et.al, 2011) }\end{array}$ & 0.192 & $50 \%$ & $10 \%$ & 0.0015 \\
\hline & & & $\begin{array}{l}\text { Satisfaction audit of employees and professors(Tseng, } \\
\text { 2010) }\end{array}$ & 0.239 & 9 & 1 & 0.001 \\
\hline & & & The number of expert force left in organization & 0.569 & 0 & 8 & 0 \\
\hline & \multirow{2}{*}{$\begin{array}{l}\text { S12. Enhancing the competitive } \\
\text { advantages of university in proportion } \\
\text { to other competitors }\end{array}$} & \multirow{2}{*}{0.0934} & $\begin{array}{l}\text { The flexibility of service delivering system in } \\
\text { university(Wu et al., 2011) }\end{array}$ & 0.077 & 9 & 3 & 0.0024 \\
\hline & & & $\begin{array}{l}\text { the number of student complaint to meritorious reference } \\
\text { for the unit (central organization, governor and ...) } \\
\text { (Tseng, 2010) }\end{array}$ & 0.923 & 0 & 22 & 0 \\
\hline & \multirow{2}{*}{$\begin{array}{l}\text { S13. Updating the job training and } \\
\text { empowerment of scientific boards } \\
\text { (software power enhancement of } \\
\text { university) }\end{array}$} & \multirow{2}{*}{0.0605} & educational opportunities abroad & 0.936 & $20 \%$ & $1 \%$ & 0.0028 \\
\hline & & & the promotion percentage in faculty member & 0.064 & $20 \%$ & $12 \%$ & 0.0023 \\
\hline & \multirow{2}{*}{$\begin{array}{l}\text { S15. Promotion of organizational } \\
\text { culture }\end{array}$} & \multirow[t]{2}{*}{0.0313} & the extent of dependency spirit in employees (pluralism) & 0.394 & 9 & 4 & 0.0055 \\
\hline & & & the extent of uncertainty in organization & 0.606 & 1 & 8 & 0.0024 \\
\hline & $\begin{array}{l}\text { S1. Identifying thee applied fields in } \\
\text { survey scientific communities of the } \\
\text { country. }\end{array}$ & 0.0356 & $\begin{array}{l}\text { the number of performed/performing educational plans in } \\
\text { this field }\end{array}$ & 1 & 5 & 1 & 0.0071 \\
\hline & \multirow{3}{*}{$\begin{array}{l}\text { S7. Developing creativity and } \\
\text { innovative culture in students and } \\
\text { professors }\end{array}$} & \multirow{3}{*}{0.0211} & $\begin{array}{l}\text { the number of bespoke educational terms from students } \\
\text { and faculty members side(Wu et.al., 2011) }\end{array}$ & 0.037 & $10 \%$ & $1 \%$ & 0.0001 \\
\hline & & & the amount of paid awards(Wu et.al., 2011) & 0.027 & $10 \%$ & $1 \%$ & 0 \\
\hline & & & $\begin{array}{l}\text { the percentage of new ideas transferrable to delivered } \\
\text { product to the growth centers }\end{array}$ & 0.936 & $50 \%$ & $1 \%$ & 0.0004 \\
\hline & Total & 1 & ----- & 17 & --- & --- & 0.2577 \\
\hline
\end{tabular}

*: by multiple of comparative quantities in the 3rd columns (the weight of strategic objectives), the 5th columns (the weight of performance indexes) and the proportion of status que quantities ideal quantities, the quantities of performance evaluation column; will be calculated. The total of this numerical column will be between zero and one. 
Table 9

The result of BSC implementation

\begin{tabular}{lcc}
\hline Perspectives & Performance & object \\
\hline $\begin{array}{l}\text { Customer and scientific } \\
\text { credits }\end{array}$ & 0.063 & 0.201 \\
Financial & 0.055 & 0.150 \\
Internal Processes & 0.071 & 0.325 \\
\hline Learning & 0.054 & 0.325 \\
\hline Total & 0.242 & 1.000 \\
\hline
\end{tabular}

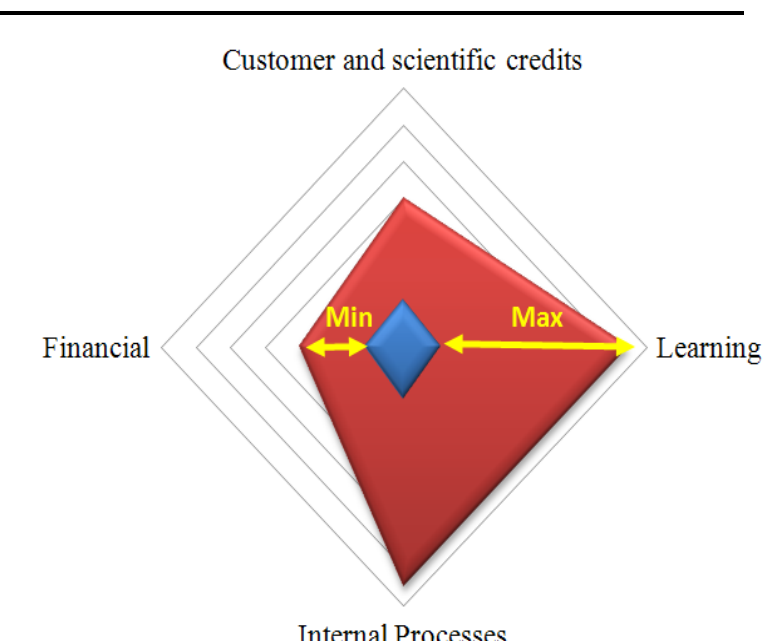

Fig. 1. The result description by describing balanced scorecard perspectives

\section{Table 10}

Result description by describing macro objective

\begin{tabular}{clcc}
\hline Macro objective & Performance & object \\
\hline $\mathrm{O}_{1} \quad \begin{array}{l}\text { It can improve the efficient and effective relations with industries for financial } \\
\text { dependence on student's fee by increasing hardware and software capabilities. }\end{array}$ & 0.143 & 0.478 \\
$\mathrm{O}_{2} \quad \begin{array}{l}\text { Creating an efficient system of intellectual and moral ownership for the sale of } \\
\text { scientific patents. }\end{array}$ & 0.071 & 0.158 \\
$\mathrm{O}_{3} \quad \begin{array}{l}\text { Developing and equipping in order to promoting the university at least in one of the } \\
\text { introduced scientific educational field in the country. }\end{array}$ & 0.081 & 0.289 \\
$\mathrm{O}_{4} \quad \begin{array}{l}\text { Creating and equipment of the growth centers for converting the scientific results to } \\
\text { saleable scientific patents. }\end{array}$ & 0.104 & 0.226 \\
$\mathrm{O}_{5} \quad \begin{array}{l}\text { IT application and its institutionalization in key processes of the university. } \\
\mathrm{O}_{6} \quad \begin{array}{l}\text { Creation of incentive points for development of software capitals (human for } \\
\text { enabling the staffs and faculty members in universities) }\end{array}\end{array}$ & 0.067 & 0.052 & 0.292 \\
\hline
\end{tabular}

Guideline: blue colored levels: Performance 
Table 11

The result description by describing strategic objectives

\begin{tabular}{|c|c|c|c|c|}
\hline \multirow{2}{*}{ strategic objectives } & \multicolumn{2}{|c|}{ Status que quantities } & \multicolumn{2}{|c|}{ Ideal quantities } \\
\hline & Performance & $\begin{array}{c}\text { Proportion of } \\
\text { objectives }\end{array}$ & object & $\begin{array}{c}\text { Proportion of } \\
\text { objectives }\end{array}$ \\
\hline $\begin{array}{l}\mathrm{S}_{1} \text {. Identifying thee } \\
\ldots\end{array}$ & 0.007 & $20 \%$ & 0.036 & $100 \%$ \\
\hline $\mathrm{S}_{2}$. developing the $\ldots$ & 0.004 & $5 \%$ & 0.084 & $100 \%$ \\
\hline $\mathrm{S}_{3}$. Creation and $\ldots$ & 0.017 & $33 \%$ & 0.051 & $100 \%$ \\
\hline $\begin{array}{l}\mathrm{S}_{4} . \text { Enhancement of } \\
\ldots\end{array}$ & 0.015 & $38 \%$ & 0.040 & $100 \%$ \\
\hline $\mathrm{S}_{5}$. Effective $\ldots$ & 0.005 & $12 \%$ & 0.039 & $100 \%$ \\
\hline $\mathrm{S}_{6}$. Developing ... & 0.034 & $50 \%$ & 0.069 & $100 \%$ \\
\hline $\mathrm{S}_{7}$. Developing ... & 0.001 & $2 \%$ & 0.021 & $100 \%$ \\
\hline $\mathrm{S}_{8}$. Developing the $\ldots$ & 0.047 & $30 \%$ & 0.160 & $100 \%$ \\
\hline $\mathrm{S}_{9}$. Enhancing the $\ldots$ & 0.053 & $50 \%$ & 0.106 & $100 \%$ \\
\hline $\mathrm{S}_{10}$. Enhancing the $\ldots$ & 0.000 & $0 \%$ & 0.060 & $100 \%$ \\
\hline $\mathrm{S}_{11}$.efficiency $\ldots$ & 0.002 & $5 \%$ & 0.045 & $100 \%$ \\
\hline $\mathrm{S}_{12}$. Enhancing the $\ldots$ & 0.002 & $3 \%$ & 0.093 & $100 \%$ \\
\hline $\begin{array}{l}\mathrm{S}_{13} \text {. Updating the job } \\
\ldots\end{array}$ & 0.005 & $9 \%$ & 0.061 & $100 \%$ \\
\hline $\mathrm{S}_{14 .}$ Creating an ... & 0.011 & $50 \%$ & 0.021 & $100 \%$ \\
\hline $\mathrm{S}_{15}$. Promotion of $\ldots$ & 0.008 & $25 \%$ & 0.031 & $100 \%$ \\
\hline $\begin{array}{l}\mathrm{S}_{16} . \mathrm{IT} \text { development } \\
\ldots\end{array}$ & 0.028 & $64 \%$ & 0.044 & $100 \%$ \\
\hline $\mathrm{S}_{17}$. Enforcing the $\ldots$ & 0.003 & $6 \%$ & 0.039 & $100 \%$ \\
\hline Total & 0.242 & $24 \%$ & 1.000 & --- \\
\hline
\end{tabular}
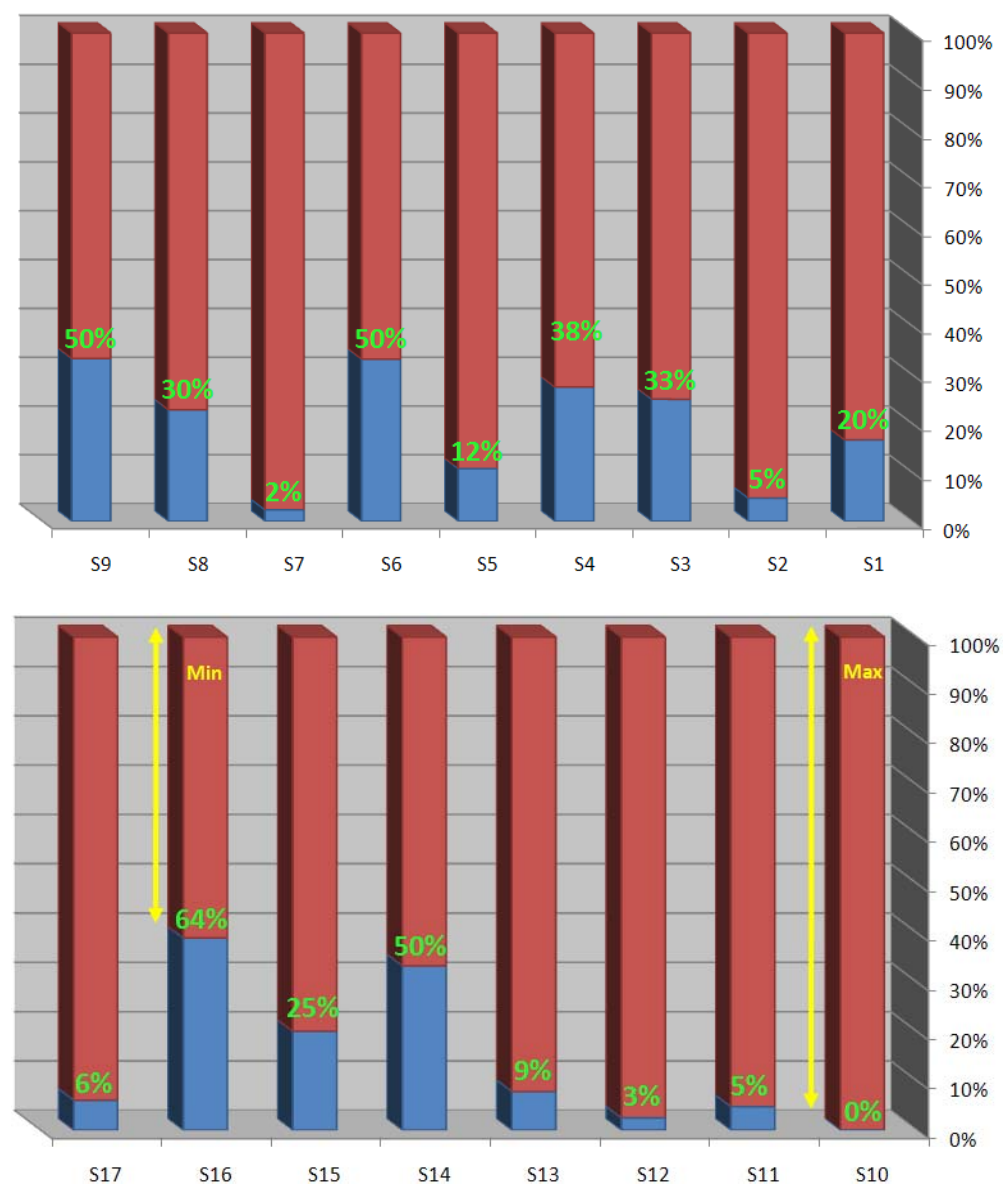

Fig. 3. The result description by describing strategic objectives 


\section{Conclusions}

In this paper, we have presented BSC as one of the most applicable and strongest performance evaluation methods. One of the implementation levels of this successful performance evaluation system is the application of strategic innovation for system institutionalization in organization. Researchers visualized a new structure for implementation of BSC in this field by utilizing the strength of available administrative methods and the administrative power of model was proved by experimental implementation of suggested structure in an educational organization. In addition, the results of the implementation of the proposed model of his paper in Semnan Islamic Azad University showed that multi criteria decision making techniques can be applied by a systematic and structured methodology .

\section{Acknowledgement}

We should thank and appreciate the Semnan Islamic Azad University and expert groups because of material and mental supports .

\section{References}

Achterbergh, J., Beeres, R., \& Vriens, D. (2003). Does the balanced scorecard support organizational viability?. Kybernetes. 32, 1387-1404.

Agrawal, S. (2008). Competency Based Balanced Scorecard Model: An Integrative Perspective. Indian Journal of Industrial Relations, 44(1), 12-18.

Baldwin, C.Y., \& Clark, K.B. (1992). Capabilities and Capital Investment: New Perspectives on Capital Budgeting. Journal of Applied Corporate Finance, 5(2), 67-82.

Blokdijk, G. (2008). Balanced scorecard 100 success secrets, 100 most asked questions on approach, development, management, measures, performance and strategy. Emereo Pty Ltd.

Bukh, P.N., \& Malmi, T. (2005). Reexamining cause-and-effect principal of the balances scorecard. In J. Mourtisen, S. Jönsson (Eds.). Northern Lights in Accounting. Stockholm, Liber.

Bulut, E., Duru, O., Kececi, T., \& Yoshida, S. (2012). Use of consistency index, expert prioritization and direct numerical inputs for generic fuzzy-AHP modeling: A process model for shipping asset management. Expert Systems with Applications, 39(2), 1911-1923.

Bunker, R.D., Chang, H., Janakiraman, S.N., \& Konstans, C. (2004). A balanced scorecard analysis performance metrics. European Journal of Operational Research, 154(2), 423-436.

Buytendijk, F., Hatch, T., \& Micheli, P. (2010). Scenario-based strategy maps. Business Horizons. 53: 335347 .

Cebeci, U. (2009). Fuzzy AHP-based decision support system for selecting ERP systems in textile industry by using balanced scorecard. Expert Systems with Applications, 36(5), 8900-8909.

Chang, B., Chang, C.W., \& Wu, C.H. (2011). Fuzzy DEMATEL method for developing supplier selection criteria. Expert Systems with Applications, 38(3), 1850-1858.

Chen, J.K., \& Chen, I.S. (2010). Using a novel conjunctive MCDM approach based on DEMATEL, fuzzy ANP, and TOPSIS as an innovation support system for Taiwanese higher education. Expert Systems with Applications, 37(3), 1981-1990.

Chen, J.K., \& Chen, I.S. (2010). Using a novel conjunctive MCDM approach based on DEMATEL, fuzzy ANP, and TOPSIS as an innovation support system for Taiwanese higher education. Expert Systems with Applications, 37(3), 1981-1990.

Chen, S.H., Yang, C.C., \& Shiau, J.Y. (2006). The application of balanced scorecard in the performance evaluation of higher education. The TQM Magazine. 18(2), 190-205 .

Chiang, Z. (2005). A dynamic decision approach for long-term vendor selection based on AHP and BSC. ICIC. 2005 .

Clinton, B.D., Webber, S.A., \& Hassel, J.M. (2002). Implementing the balanced scorecard Using the analytic hierarchy process, Management Accounting Quarterly, 3(3), 1-11.

Cross, K.F., \& Lynch, R.L. (1988). The SMART way to define and success. National Productivity Review, $8(1), 20-25$. 
De Waal, A.A. (2010). Performance-driven behavior as the key to improved organizational performance. Journal of Measurement Business Excellence. 14(1), 79- 95.

Evans, J.R., \& Lindsay, W.M. (2005). The Management and Control of Quality. Mason Oh.: Thomson SouthWestern.

Grigoroudis, E., Orfanoudaki, E., \& Zopounidis, C. (2012). Strategic performance measurement in a healthcare organization: A multiple criteria approach based on balanced scorecard. Omega, 40(1), 104-119.

Gulick, L., \& Urwick, L. (1937). Papers on the Science of Administration. N.Y., Ins. Public Administration.

HassabElnaby, H.R., Mohammad, E., Amal, A., \& Said, A.A. (2010). Nonfinancial Performance Measures and Earnings Management. Advances in Manage. Accounting, 18, 55-79.

Hsu, T.H., Hung, L.C., \& Tang, J.W. (2012). A hybrid ANP evaluation model for electronic service quality. Applied Soft Computing, 12(1), 72-81.

Huang, H.C., Lai, M.C., \& Lin, L.H. (2011). Developing strategic measurement and improvement for the biopharmaceutical firm: Using the BSC hierarchy. Expert Systems with Applications, 38(5), 4875-4881.

Jassbi, J., Mohamadnejad, F., \& Nasrollahzadeh, H. (2011). A Fuzzy DEMATEL framework for modeling cause and effect relationships of strategy map. Expert Systems with Applications, 38, 5967-5973.

Javanbarg, M.B., Scawthorn, C., Kiyono, J., \& Shahbodaghkhan, B. (2012). Fuzzy AHP-based multicriteria decision making systems using particle swarm optimization. Expert Systems with Applications, 39(1), 960966.

Jyoti, B. D. K., \& Deshmukh, S.G. (2008). Evaluating Performance of National R\&D Organizations Using Integrated DEA-AHP Technique. International Journal of Production Performance Management, 57(5), 370-388.

Kaplan, R.S., \& Norton, D.P. (2002). Building the Balanced Scorecard in Public Sector. Balanced Scorecard Report from Interview with Rick Pagsibigan, September 19.

Kaplan, R.S., \& Norton, D.P. (2004). Strategy maps: Converting intangible assets into tangible outcomes. Boston, MD: Harvard Bus. School Press.

Kaplan, R.S., \& Norton, D.P. (2000). The strategy-focused organization: How balanced scorecard companies thrive in the new business environment. Harvard Bus. School Press.

Kaplan, R.S., \& Norton, D.P. (1996). Using the Balanced Scorecard as a Strategic Management System. Harvard Bus. Review (January.February). 74(1), 75-85.

Kuoa, M.S., \& Liang, G.S. (2011). A novel hybrid decision-making model for selecting locations in a fuzzy environment. Mathematical and Computer Modelling, 54(1-2), 88-104.

Lebas, M.J. (1995). Performance Measurement and Performance Management. International Journal of Production Economics. 41(1-3), 23-35.

Lee, W.S., Huang, A.Y., Chang, Y.Y., \& Cheng, C.M. (2011). Analysis of decision making factors for equity investment by DEMATEL and Analytic Network Process. Expert Systems with Applications, 38(7), 83758383.

Lee, Y.C., Li, M.L., Yen, T.M., \& Huang, T.H. (2011). Analysis of fuzzy Decision Making Trial and Evaluation Laboratory on technology acceptance model. Expert Systems with Applications, 38(12), 1440714416.

Lester, D.L., Parnell, J.A., \& Carraher, S. (2010). Assessing the Desktop Manager. Journal of Management Development. 29(3), 246-264.

Makhijani, N., \& Creelman, J. (2008). How leading organizations successfully implement corporate strategy with the balanced scorecard. The OTI Thought Leadership Series, 1, 1-16.

Maltz, A.C., Shenhar, A.J., \& Reilly, R.R. (2003). Beyond the Balanced Scorecard: Refining the Search for Organizational Success Measures. Long Range Planning, 36(2), 187-204.

Neely, A.D., \& Adams, C.A. (2000). Perspective on performance: the performance prism, centre for business performance. Cranfield School of Manage, UK.

Neely, A.D., Gregory, M., \& Platts, K. (1995). Performance measurement system design: A literature review and research agenda. International Journal of Operations and Production Management, 15(4), 80-116.

Nissen, V. (2006). Modeling corporate strategy with the fuzzy balanced scorecard. In: Hüllermeier E, Kruse R, Nürnberger A, Strackeljan J (eds.): Proceedings Symposium on Fuzzy Systems in Computer Science FSCS 2006, Magdeburg. 121-138.

Niven, P. (2002). Balanced Scorecard step by step: Maximizing Performance and Maintaining Results. New York: John Willy \& Sons.

Niven, P.R. (2006). Balanced scorecard step-by-step: Maximizing performance and maintaining results. 2nd ed. John Wiley \& Son. 
Oh, Y., Suh, Eh., Hong, J., \& Hwang, H. (2009). A feasibility test model for new telecom service development using MCDM method: A case study of video telephone service in Korea. Expert Systems with Applications, 36(3), 6375-6388.

Özkır V, Demirel T (2012). A fuzzy assessment framework to select among transportation investment projects in Turkey. Expert Systems with Applications, 39(1), 74-80 .

Prowse P, Prowse J (2009). The Dilemma of Performance Appraisal. Journal of Measurement Business Excellence, 13(4), 69-77.

Quezad, L.E., Cordova, F.M., Palominos, P., Godoy, K., \& Ross, J. (2009). Method for identifying strategic objectives in strategy maps. International Journal of Production Economics, 122, 492-500.

Ramstad, E. (2009). Promoting Performance and the Quality of Working Life Simultaneously. International Journal of Production Performance Management, 58(5), 423-436.

Ravi, V., Shankar, R., \& Tiwari, M.K. (2005). Analyzing alternatives in reverse logistics for endoflife computers. ANP and balanced scorecard approach. Computers and Industrial Engineering. 48(2), 327-356.

Sevkli, M., Oztekin, A., Uysal, O., Torlak, G., Turkyilmaz, A., \& Delen, D. (2012). Development of a fuzzy ANP based SWOT analysis for the airline industry in Turkey. Expert Systems with Applications, 39(1), 1424.

Seyed-hosseini, S.M., Ebrahimi, T.A., Bakhsha, A., \& Partovi, S. (2011). Extracting leanness criteria by employing the concept of Balanced Scorecard. Expert Systems with Applications, 38(8), 10454-10461.

Simons, R. (2000). Performance Measurement Control Systems for Implementing Strategy, N. J.: Prentice Hall. 5-35.

Sohn, M.H., You, T., Lee, S.L., \& Lee, H. (2003). Corporate strategies, environmental forces, and performance measures: a weighting decision support system using k-nearest neighbor technique. Expert Systems with Applications, 25(3), 279-292.

Sole, F. (2009). A management model and factors driving performance in public organizations. Measuring Business Excellence, 13(4), 3-11.

Stwart, R.A., \& Mohamed, S. (2001). Utilizing the Balanced scorecard for IT/IS performance evaluation in construction. Construction Innovation: Information, Process, Manage, 1(3), 147-163.

Tohidi, H., Jafari, A., Azimi Afshar, A. (2010a). Strategic planning in Iranian educational organizations. Procedia Social and Behavioral Sciences, 2(2), 3904-3908.

Tohidi, H., Jafari, A., \& Azimi Afshar, A. (2010b). Using balanced scorecard in educational organizations. Procedia Social and Behavioral Sciences. 2(2), 5544-5548.

Tseng, M.L. (2010). Implementation and performance evaluation using the fuzzy network balanced scorecard. Computers \& Education, 55(1), 188-201.

Wang, X., Chan, H.K., Yee, R.W.Y., \& Diaz-Rainey, I. (2012). A two-stage fuzzy-AHP model for risk assessment of implementing green initiatives in the fashion supply chain. International Journal of Production Economics, 135(2), 595-606.

Wu, H.Y., Lin, Y.K., \& Chang, C.H. (2011). Performance evaluation of extension education centers in universities based on the balanced scorecard. Evaluation and Program Planning, 34(10), 37-50.

Wu, H.Y., Tzeng, G.H., \& Chen, Y.H. (2009). A fuzzy MCDM approach for evaluating banking performance based on Balanced Scorecard. Expert Systems with Applications, 36(6), 10135-10147.

Wu, W.W., \& Lee, Y.T. (2007). Developing global managers' competencies using the fuzzy DEMATEL method. Expert Systems with Applications, 32(2), 499-507.

$\mathrm{Xu}, \mathrm{Y} .$, \& Yeh, C.H. (2012). An integrated approach to evaluation and planning of best practices. Omega, $40(1), 65-78$.

Yan, X., \& Chang-Hsing, Y. (2012). An integrated approach to evaluation and planning of best practices. Omega, 40(1), 67-78.

Zheng, G., Zhu, N., Tian, Z., Chen, Y., \& Sun, B. (2012). Application of a trapezoidal fuzzy AHP method for work safety evaluation and early warning rating of hot and humid environments. Safety Science, 50(2), 228-239.

Zhou, Q., Huang, W., \& Zhang, Y. (2011). Identifying critical success factors in emergency management using a fuzzy DEMATEL method. Expert Systems with Applications, 49(2), 243-259. 